\title{
Detection of tick-borne rickettsial pathogens in naturally infected dogs and dog-associated ticks in Medellin, Colombia
}

\author{
Detecção de patógenos rickettsiais transmitidos por carrapatos em cães \\ naturalmente infectados e carrapatos associados a cães em Medellin, Colômbia
}

\author{
Esteban Arroyave 1,2,* (1D; Emily Rose Cornwell³; Jere Williams McBride²; Carlos Arley Díaz'; \\ Marcelo Bahia Labruna4; Juan David Rodas
}
Grupo de Investigación en Ciencias Veterinarias - Centauro, Facultad de Ciencias Agrarias, Universidad de Antioquia, Medellín, Colombia ${ }^{2}$ Department of Pathology, Center for Biodefense and Emerging Infectious Diseases, Sealy Institute for Vaccine Development, University of Texas Medical Branch, Galveston, TX, USA
${ }^{3}$ Department of Microbiology and Immunology, College of Veterinary Medicine, Cornell University, Ithaca, NY, USA
${ }^{4}$ Faculdade de Medicina Veterinária e Zootecnia, Universidade de São Paulo - USP, São Paulo, SP, Brasil

How to cite: Arroyave E, Cornwell ER, McBride JW, Díaz CA, Labruna MB, Rodas JD. Detection of tick-borne rickettsial pathogens in naturally infected dogs and dog-associated ticks in Medellin, Colombia. Braz J Vet Parasito/ 2020; 29(3): e005320. https://doi. org/10.1590/S1984-29612020060

\begin{abstract}
Tick-borne rickettsial pathogens (TBRP) are important causes of infections in both dogs and humans. Dogs play an important role as a biological host for several tick species and can serve as sentinels for rickettsial infections. Our aim was to determine the presence of TBRP in dogs and in dog-associated ticks and their potential risk to human diseases in Medellin, Colombia. DNA for E. canis (16S rRNA and dsb) and A. platys (groEl) was detected in $17.6 \%$ (53/300) and 2.6\% (8/300) of dogs, respectively. Antibodies against Ehrlichia spp. 82 (27.3\%) and Anaplasma spp. 8 (2.6\%) were detected in dogs. Antibody reactivity against both agents were found in 16 dogs (5.3\%). Eight dogs showed antibody for Rickettsia spp. with titers that suggest 3 of them had a probable exposure to R. parkeri. Rhipicephalus sanguineus s.I. (178/193) was the main tick in dogs, followed by R. microplus (15/193). The minimum infection rates (MIR) in $R$. sanguineus were $11.8 \%$ for $E$. canis and $3.4 \%$ for $A$. platys. E. canis and A. platys are the main TBRP infecting dogs and ticks and $R$. sanguineus s.l. is likely involved in the transmission of both agents. Interestingly, we found serological evidence of exposure in dogs for spotted fever group rickettsiae.
\end{abstract}

Keywords: Tick-borne diseases, Rickettsiales, Rhipicephalus sanguineus, dogs, Colombia.

\begin{abstract}
Resumo
As riquétsias transmitidas por carrapatos (RTC) são causas importantes de infecção em cães e humanos. Os cães exercem um papel essencial como hospedeiros biológicos para diversas espécies de carrapatos, assim como podem ser úteis como sentinelas de infecções por riquétsias. O intuito deste estudo foi determinar a presença de RTC em cães, assim como em seus carrapatos, para determinar o risco potencial de doença humana em Medellín, Colômbia. DNA de Ehrlichia canis (16S rRNA e dsb) e Anaplasma platys (groEl) foi detectado em 17,6\% (53/300) e 2,6\% (8/300) dos cães, respectivamente. Anticorpos contra Ehrlichia spp. (82; 27,3\%) e Anaplasma spp. (8; 2,6\%) foram detectados nos cães. Reatividade de anticorpos contra ambos patógenos (Ehrlichia e Anaplasma) foi detectada em 16 cães (5,3\%). Oito animais apresentaram anticorpos contra Rickettsia spp., e 3 deles sugerem uma provável exposição a Rickettsia parkeri. Rhipicephalus sanguineus s.l. (178/193) foi a principal espécie de carrapatos, seguida de R. microplus (15/193). A taxa de infecção mínima em $R$. sanguineus foi 11,8\% para E. canis e 3,4\% para A. platys. E. canis e $A$. platys são as principais RTC que infectam cãese $R$. sanguineus s.l. provavelmente está envolvido na transmissão de ambos os agentes. É evidente, porém, a exposição sorológica dos cães a riquétsias do grupo da febre maculosa.
\end{abstract}

Palavras-chave: Doenças transmitidas por carrapatos, Rickettsiales, Rhipicephalus sanguineus, cães, Colômbia.

Received March 17, 2020. Accepted June 04, 2020

Financial support: This work was supported by Colciencias (process number 569/2012).

*Corresponding author: Esteban Arroyave E-mail: estebanarro83@gmail.com

This is an Open Access article distributed under the terms of the Creative Commons Attribution License, which permits unrestricted use distribution, and reproduction in any medium, provided the original work is properly cited. 


\section{Introduction}

Obligate intracellular bacteria of the order Rickettsiales cause several tick-borne diseases of human and veterinary medical importance. This order encompasses two families: Anaplasmataceae that includes several pathogens of humans and animals within the genera Ehrlichia and Anaplasma, which are transmitted by species of ixodid ticks to mammalian hosts (Rar \& Golovljova, 2011) and Rickettsiaceae containing pathogenic Rickettsia species that are found throughout the world and continue to emerge and reemerge as important causes of febrile illnesses in humans and numerous domestic and wild animals (Fang et al., 2017). Dogs are considered important sentinel animals for human rickettsial infection since they may suffer a clinical illness similar to humans or may be asymptomatic and chronically infected, serving as reservoir host. Even if dogs are not the main reservoirs, or amplifying hosts for rickettsial pathogens, they may serve as definitive feeding hosts for ticks or carry ticks infected by these pathogens to human dwellings (Sabatini et al., 2010; Nieri-Bastos et al., 2013; Szabó et al., 2013).

Ehrlichia canis and Anaplasma platys are the etiological agents of Canine Monocytic Ehrlichiosis (CME) and Canine Infectious Cyclic Thrombocytopenia (CICT), respectively. These agents are the most common tick-borne pathogens detected in dogs in places around the world where Rhipicephalus sanguineus sensu lato (s.l.) is present (Sainz et al., 2015; Cárdenas et al., 2007). Ehrlichia canis is also considered the agent of an emerging zoonosis in Latin America (Carvalho et al., 2017; Bouza-Mora et al., 2017). Rickettsia rickettsii is the etiologic agent of Rocky Mountain spotted fever (RMSF), the severest tick-borne human disease in the Americas. Dogs can serve as sentinels in endemic regions for RMSF because, like humans, they are susceptible to infection with $R$. rickettsii with potentially fatal outcomes, and they have relatively high rates of exposure to infected ticks (Breitschwerdt et al., 1985; Demma et al., 2005; Piranda et al., 2008; Labruna et al., 2009; Levin et al., 2014). Recently, other species of the spotted fever group rickettsiae (SFG) such as $R$. parkeri and $R$. massiliae have been associated with infection in humans and dogs from South America (Spolidorio et al., 2010; Cicuttin et al., 2004; Londoño et al., 2014).

Cases of canine infectious cyclic thrombocytopenia by $A$. platys and RMSF by $R$. rickettsii in dogs could easily be misdiagnosed and confused with CME by $E$. canis since these three pathogens share clinical signs and also could be transmitted by the same vector, the brown dog tick, Rhipicephalus sanguineus (s.I.) (Grindem et al., 1999; Piranda et al., 2008; Labruna et al., 2009). Clinical disease in dogs experimentally and naturally infected with E. canis, A. platys and $R$. rickettsii results in variable and nonspecific clinical signs, such as fever, lethargy, anorexia, weight loss, pale mucous membranes, petechiae, nasal discharge, and lymphadenopathy (Harvey, 2006). Although CICT tends to be less severe than CME or RMSF, co-infection by A. platys with other tick-borne pathogens could exacerbate the clinical manifestations (Sainz et al., 2015; Gaunt et al., 2010).

$R$. sanguineus s.l. is considered the most widespread ectoparasite in dogs in the world and also a well-recognized vector of numerous pathogens for dogs and humans (Dantas-Torres, 2008). This tick is the main vector of $E$. canis and A. platys, although its vector competence for A. platys has not been firmly established (Simpson et al., 1991; Aktas \& Özübek, 2017; Ipek et al., 2018). Even though $R$. sanguineus s.l. rarely feeds on humans, it has been involved in the transmission of $R$. rickettsii in two recent RMSF outbreaks in the United States and Mexico, where stray and free-roaming dogs appeared to play an important role in the propagation and the dispersal of infected ticks (Demma et al., 2006; Álvarez-Hernández et al., 2017).

The first study about tick-borne rickettsial diseases on humans in Colombia occurred during an outbreak between 1934 and 1936 in Tobia, Department of Cundinamarca, and was named "Tobia spotted fever", which was caused by $R$. rickettsii (Patiño et al., 1937; Patiño, 1941). Seventy years later, two new fatal cases of RMSF were confirmed in the same region (Hidalgo et al., 2007). A year later, a serological survey was conducted in domestic animals, finding that $18 \%$ and $31.8 \%$ of dogs had antibodies to spotted fever group (SFG) rickettsiae and Ehrlichia spp., respectively (Hidalgo et al., 2009). In northwest Colombia, the second known endemic area of RMSF, the R. parkeri strain Atlantic rainforest was isolated from Amblyomma ovale ticks collected from a dog, and a human case of mild rickettsiosis was reported (Londoño et al., 2014; Acevedo-Gutiérrez et al., 2019). Nevertheless, no clinical cases due to any SFG rickettsiae have been documented in dogs in Colombia. Conversely, seroepidemiological data suggest that the frequency of antibodies to Ehrlichia spp. and Anaplasma spp. in dogs vary between 23 and 80\%, and 11 and 53\%, respectively (Hidalgo et al., 2009; McCown et al., 2014a,b). The aim of the present work was to investigate serological and molecular evidence of tick-borne rickettsial pathogens (TBRP) in dogs and in dog-associated ticks and their potential risk to human diseases in Medellin city, Colombia. 


\section{Materials and Methods}

\section{Sample collection}

The study was performed between July 2013 and January 2015. Blood samples were collected from 300 dogs that were referred to two veterinary teaching hospitals in the metropolitan area of Medellin city, Colombia. We considered as inclusion criteria, dogs that presented with non-specific clinical signs associated with CME such as fever, lethargy, anorexia, and weight loss. In addition, we included apparently healthy dogs in which the owner reported tick infestation one year before the consultation.

Blood was obtained from the cephalic vein, collected into sterile tubes with anticoagulant (EDTA), and kept at $4^{\circ} \mathrm{C}$ until arrival to the laboratory. Subsequently, whole blood $(1 \mathrm{~mL})$ was aliquoted for DNA extraction, and the remaining sample was centrifuged at $700 \times \mathrm{g}$ for $10 \mathrm{~min}$ to obtain plasma. All dogs included underwent a hematological test through Abacus Junior Vet ${ }^{\circledR}$, Diatron normalized hematologic analysis device, the hematology panel included RBCs

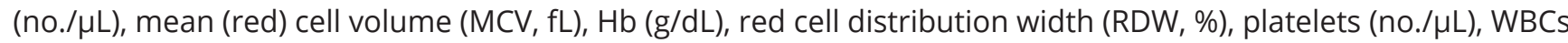

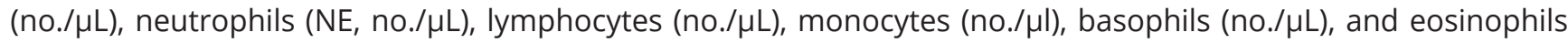
$(\mathrm{no} . / \mu \mathrm{L})$. Hematological values of dogs with detected rickettsial pathogens were compared with defined reference values of healthy dogs (Bossa-Miranda et al., 2012).

The whole blood and plasma were stored at $-80^{\circ} \mathrm{C}$. Ticks retrieved from the sampled dogs were immediately transported to the laboratory and identified using the taxonomic key of Onofrio et al. (2006). The ticks were separated into pools of no more than 4 specimens each, by species, developmental stage and sex, and stored at $-80^{\circ} \mathrm{C}$ until DNA extraction.

\section{Serologic testing}

Canine plasma was tested by immunofluorescence assay (IFA) using DH82 cells infected with E. canis strain Jake (USA) and Vero cells infected with $R$. rickettsii strain Sheila Smith as previously described (McBride et al., 2001; Horta et al., 2004). Samples showing reactivity at a dilution of 1:100 for E. canis and 1:64 for $R$. rickettsii were further titrated using serial 2-fold dilutions to determine the endpoint IgG titer. Additionally, samples positive at a titer $\geq 1: 64$ in the screening test with $R$. rickettsii antigens were also tested with four antigens derived of rickettsial isolates from Brazil including $R$. bellii strain Mogi, $R$. amblyommatis strain Ac37, R. felis strain Pedreira and R. parkeri strain At24. Plasma showing a titer at least fourfold higher than that observed for any other Rickettsia species was considered homologous to the highest titer Rickettsia species or to a very closely related strain (Saito et al., 2008). Sera from dogs experimentally infected with $E$. canis and $R$. rickettsii and negative dog plasma were used as positive and negative controls, respectively. The slides were incubated with fluorescein isothiocyanate-labelled rabbit anti-dog IgG (Sigma, St Louis, MO, USA) as the secondary antibody reagent. In addition, the commercial enzyme-linked immune-sorbent assay (ELISA) SNAP 4DX ${ }^{\circledR}$ Plus (IDEXX Laboratories, Inc., Westbrook, Maine) was used for the detection of antibodies against Anaplasma spp., (Stillman et al., 2014) according to manufacturer's recommendations.

\section{PCR amplification and sequencing}

Genomic DNA was extracted from $200 \mu \mathrm{L}$ of whole blood samples using a DNeasy ${ }^{\otimes}$ Blood \& Tissue kit according to the manufacturer's protocol (Qiagen, Chatsworth, CA, USA). Nucleic acid was eluted into $100 \mu \mathrm{L}$ of elution buffer and stored at $-80^{\circ} \mathrm{C}$ for molecular detection. PCR amplification was performed by targeting the following genes (Table 1).

Each reaction was amplified using $1 U$ of platinum Taq DNA Polymerase (Invitrogen, Brazil), PCR buffer (20 mM Tris- $\mathrm{HCl}), 1.5 \mathrm{mM} \mathrm{MgCl}$, dNTP mixture (0.2 mM each) (Invitrogen, USA), 100-200 ng of DNA template, and ultrapure water from Milli-Q with DEPC (AMRESCO) in a final volume of $25 \mu \mathrm{L}$. DNA from E. canis, A. platys and R. rickettsii were used as positive controls, and DNA from an uninfected dog blood was used as a negative control. The PCR was performed in a thermal cycler (Bio-Rad Laboratories, Hercules, CA, USA), using a cycling protocol of $94^{\circ} \mathrm{C}$ for $5 \mathrm{~min}$ and $35 \mathrm{cycles}$ of $94^{\circ} \mathrm{C}$ for $30 \mathrm{~s}, 58^{\circ} \mathrm{C}$ for $30 \mathrm{~s}$ and $72^{\circ} \mathrm{C}$ for $1 \mathrm{~min}$, for $16 \mathrm{~S} \mathrm{rRNA}$ and groEl genes, and the annealing temperature for $g / t A$ and $d s b$ were $54^{\circ} \mathrm{C}$ and $48^{\circ} \mathrm{C}$ for $30 \mathrm{~s}$, respectively. The amplified products were separated on a $2 \%$ agarose gel Tris Acetate-EDTA electrophoresis, and visualized by staining with DNA GelRed (Biotium ${ }^{\circledR}$, Fremont, CA, USA). To confirm the absence of PCR inhibitors in DNA extractions, a fragment of $\beta$-actin (259bp) or 125 rDNA (400 bp) gene in canine or tick DNA templates, respectively, was amplified as previously described (Agudelo-Ruíz et al., 
Table 1. Primers used for the amplification of some tick-borne pathogens.

\begin{tabular}{|c|c|c|c|c|}
\hline Pathogens & Gen (bp) & Primer & Sequences & Reference \\
\hline \multirow[t]{2}{*}{ Anaplasmataceae } & $16 S$ rRNA & EHR16SD & 5'-GGTACCYACAGAAGAAGTCC-3' & \multirow{2}{*}{$\begin{array}{c}\text { Inokuma et al. } \\
(2000)\end{array}$} \\
\hline & (345) & EHR16SR & 5'-TAGCACTCATCGTTTACAGC-3' & \\
\hline \multirow[t]{2}{*}{ Ehrlichia spp. } & $d s b$ & DSB330 & 5'-GATGATGTCTGAAGATATGAAACAAAT-3' & \multirow{2}{*}{$\begin{array}{c}\text { Doyle et al. } \\
(2005)\end{array}$} \\
\hline & (409) & DSB728 & 5'-CTGCTCGTCTATTTTACTTCTTAAAGT-3' & \\
\hline \multirow[t]{2}{*}{ Anaplasma platys } & groEl & HS475F & 5'-AAGGCGAAAGAAGCAGTCTTA-3' & \multirow{2}{*}{$\begin{array}{l}\text { Inokuma et al. } \\
\qquad(2002)\end{array}$} \\
\hline & $(750)$ & HS1198R & 5'-CATAGTCTGAAGTGGAGGAC-3' & \\
\hline \multirow[t]{2}{*}{ Rickettsia spp. } & $g / t A$ & Cs-78 & 5'-GCAAGTATCGGTGAGGATGTAAT-3' & \multirow{2}{*}{$\begin{array}{l}\text { Oteo et al. } \\
\text { (2014) }\end{array}$} \\
\hline & $(401)$ & Cs-323 & 5'-GCTTCCTTAAAATTCAATAAATCAGGAT-3' & \\
\hline
\end{tabular}

2017; Murrell et al., 1999). The PCR on the ticks collected was performed in pools and the result was expressed as the minimum infection rate (MIR) representing the minimum number of ticks with detectable rickettsial pathogen, expressed as: MIR = (number of infected pools / total number of tested ticks) $\times 100$ (Anderson et al., 1993).

\section{DNA sequencing and phylogenetic analysis}

The PCR products were sequenced by Macrogen (Seoul, Korea), and the sequences (forward and reverse) were aligned using GeneStudio (2020) to obtain the consensus sequences. The alignments were made with MUSCLE (MUltiple Sequence Comparison by Log- Expectation) and the phylogenetic analyses were performed with the MEGA 7.0.26 program. Best-fitting substitution models were determined through the ML model test implemented in MEGA 7.0.26. The phylogenetic three were constructed based in Maximum-Likelihood (ML) algorithms using Tamura 3-parameter model $(\mathrm{T} 92+\mathrm{G}+\mathrm{l})$. Support for the topologies was tested by bootstrapping over 1000 replications. The sequences of A. platys obtained in this study (GenBank accession numbers MT135102 to MT135108) were aligned with 18 sequences from the groEl gene retrieved from GenBank including sequences of A. platys from South America (Venezuela: AF399916, Argentina: KR826285, KR929453 and Uruguay: KX792012), Africa (Republic of Congo: AF478129 and Zambia: LC373039) and Asia (Japan: AY077621, Thailand: KU765205 and Philippines: JN121382); to A. ovis (AF441131), A. marginale (AF414864), A. centrale (AF414866), A. phagocytophilum (EU552920) and A. bovis (JX092093); for Ehrlichia spp. we used the sequences of E. ewingii (AF195273), E. muris (KF312362) and E. canis (U96731), and as a root we used Neorickettsia risticii (U96732). All positions with less than 90\% site coverage were eliminated.

\section{Statistical analysis}

The hematological data were first tested to determine the normality of the distribution. The hematological mean values were compared among the positive dogs by PCR to Anaplasma spp. and Ehrlichia spp. Student's t-test and Mann-Whitney test were performed for the parametric and nonparametric values, respectively. The tests were implemented with SPSS Statistics for Windows Version 22.0 (SPSS, Inc., Chicago, IL, U.S.A.), and a p-value of $<0.05$ was considered to indicate statistical difference.

\section{Results}

Of the 300 canine plasma samples tested, 82 (27.3\%) contained antibodies reactive to $E$. canis with endpoint titers varying from 100 to 12,800, whereas 24 (8\%) plasma samples were seroreactive to Anaplasma spp. through the ELISA (SNAP 4DX plus) and 16 of these samples reacted to both genera (Ehrlichia and Anaplasma). Overall, 8 (2.6\%) dogs were seroreactive to the screening dilution 1:64 to $R$. rickettsii antigen by IFA. These eight canine samples were also reactive at the 1:64 dilution to some of the other Rickettsia species ( $R$. bellii, $R$. felis, $R$, amblyommatis, or R. parkeri). Among these, three canine plasma showed endpoint titers to $R$. parkeri at least 4-fold higher than those to any of the other five antigens, suggesting that $R$. parkeri or a very closely related species stimulated the antibody response in these three dogs (Table 2). 
Table 2. Indirect immunofluorescence assay (IFA) antibody titers for five Rickettsia species in canine plasma.

\begin{tabular}{ccccccc}
\hline \multirow{2}{*}{ Dog plasma } & \multicolumn{2}{c}{ IFA serological endpoint titers according to Rickettsia species } & \multicolumn{2}{c}{$\begin{array}{c}\text { Probable antigen-stimulating } \\
\text { antibody response }\end{array}$} \\
\cline { 2 - 5 } & R. parkeri & R. rickettsii & R. bellii & R. felis & R. amblyommatis & R.parkeri \\
32 & 1024 & 256 & - & - & - & R. parkeri \\
39 & 1024 & 256 & - & 64 & - & undetermined \\
81 & 256 & 128 & - & - & - & undetermined \\
89 & - & 128 & - & - & - & undetermined \\
114 & - & 64 & 64 & 64 & 64 & undetermined \\
132 & 1024 & 512 & - & 64 & - & undetermined \\
182 & 64 & 64 & - & - & - & R. parkeri \\
357 & 1024 & 64 & - & - &
\end{tabular}

$-,<1: 64$.

Ehrlichial DNA was detected in 17.6\% (53/300) of canine blood samples through the amplification of the partial fragment of the genes $16 S r R N A$ and $d s b$, showing $100 \%$ of identity with $E$. canis by phylogenetic analysis in both genes (data not shown). On the other hand, we partially sequenced the groEL gene of Anaplasma spp. in 2.6\% (8/300) canine samples. The sequences obtained by groEL exhibited $100 \%$ identity with $A$. platys. None of the canine or tick samples revealed Rickettsia DNA.

Only two tick species were collected from the dogs: 178 R. sanguineus s.l. collected from 298 dogs from urban and peri-urban, and 15 Rhipicephalus microplus ticks collected from two dogs that lived in a peri-urban area. Ticks were separated into pools of 1 to 5 individuals resulting in 69 pools of $R$. sanguineus s.l. distributed in 2 pools of larvae, 17 pools of nymphs, 20 pools of male adults and 30 pools of female adults. For $R$. microplus, we made 6 pools including one of nymphs, one of adult males and four of adult females. We detected ehrlichial DNA (dsb) in 21/69 (30.4\%) pools of $R$. sanguineus s.l. (7 nymph pools, 6 male pools and 8 female adult tick pools), and A. platys DNA (groEl) in $6 / 69$ (8\%) pools ( 3 males and 3 females adult tick pools), two of which also contained ehrlichial DNA. Interestingly, these 6 pools of ticks were retrieved from 4 dogs that were negative by PCR to A. platys, and only one of them had detectable antibodies to Anaplasma spp. The minimum infection rate (MIR) for Ehrlichia spp. and A. platys in $R$. sanguineus s.l. was $11.8 \%$ and $3.4 \%$, respectively (Table 3). All the DNA pooled samples of $R$. microplus were negative by PCR for Ehrlichia and Anaplasma spp. and no Rickettsia spp. DNA was detected in ticks.

Table 3. Number of Rhipicephalus sanguineus s.l. ticks classified by developmental stage, and MIR (Minimum Infection Rate) of Ehrlichia canis and Anaplasma platys.

\begin{tabular}{|c|c|c|c|c|c|c|}
\hline \multirow{2}{*}{$\begin{array}{c}\text { Developmental } \\
\text { stages }\end{array}$} & \multirow[b]{2}{*}{ Number of ticks } & \multirow{2}{*}{$\begin{array}{c}\text { Number of } \\
\text { pools }\end{array}$} & \multicolumn{2}{|c|}{ E. canis } & \multicolumn{2}{|c|}{ A. platys } \\
\hline & & & $\begin{array}{l}\text { Positive } \\
\text { pools }\end{array}$ & $\%$ MIR & $\begin{array}{l}\text { Positive } \\
\text { pools }\end{array}$ & $\%$ MIR \\
\hline Larva & 4 & 2 & 0 & $0(0 / 4)$ & 0 & $0(0 / 4)$ \\
\hline Nymph & 74 & 17 & 7 & $9.4(7 / 74)$ & 0 & $0(0 / 17)$ \\
\hline Adult (male) & 51 & 20 & 6 & $11.8(6 / 51)$ & 3 & $5.9(3 / 51)$ \\
\hline Adult (female) & 49 & 30 & 8 & $16.3(8 / 49)$ & 3 & $6.1(3 / 49)$ \\
\hline Total & 178 & 69 & 21 & $11.8(21 / 178)$ & 6 & $3.4(6 / 178)$ \\
\hline
\end{tabular}

All the $d s b$ sequences obtained from either dogs or ticks, shared an identity of $100 \%$ with $E$. canis. Specific PCR assays for A. platys revealed that 14 samples contained DNA of the groEl gene ( 8 dog samples and 6 tick pools). However, only 5 dog samples and 2 pools of ticks were sequenced; the remaining samples showed a weak band in the gel and poor quality sequences. Phylogenetic analysis of partial sequences from the groEl operon (655 bp) showed that the sequences from dogs and ticks shared an identity of $100 \%$ with sequences of $A$. platys from different regions, including South America (Venezuela, Argentina and Uruguay), Africa (Republic of Congo and Zambia) and Asia (Japan, Thailand and Philippines) (Figure 1). 


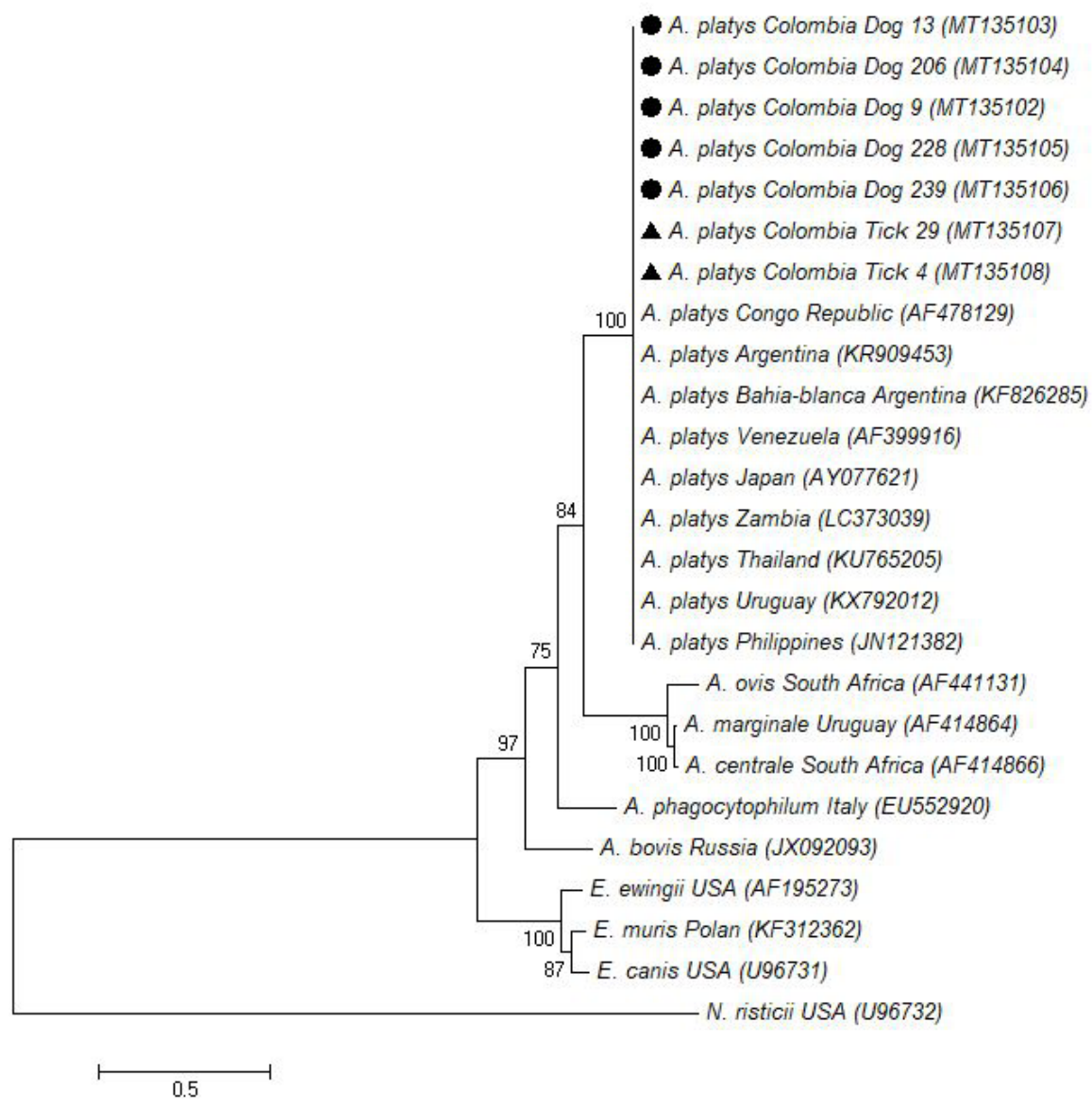

Figure 1. Maximum likelihood phylogenetic tree of groEl operon of Anaplasma platys (partial sequences, $655 \mathrm{pb}$ ) identified in this study and other strains of the Anaplasmataceae family. The numbers at the nodes represent the percentage of 1000 bootstrap resampling. dog samples, $\boldsymbol{\Delta}$ tick samples. We used the orthologous sequence groEL of Neorickettsia risticii as an outgroup.

The most common abnormal hematological findings in dogs with positive PCR for A. platys or $E$. canis were thrombocytopenia (A. platys median: $86 \times 10^{3}$ platelets count, E. canis median: $98 \times 10^{3}$ platelets count, reference value $290.8 \pm 100$ ), and low hematocrit (A. platys mean: $38.89 \% \pm 9.46$; $E$. canis mean: $36.55 \% \pm 10.72$; reference value $52.8 \pm 6.5$ ), however, there were no statistically significant differences between the hematologic parameters of canines with A. platys and those infected with E. canis (t-test or nonparametric Mann-Whitney test, $\mathrm{p}>0.05$ ).

\section{Discussion}

Overall, $92.2 \%$ (178/193) of the ticks collected from the dogs were $R$. sanguineus s.I. This result is consistent with other authors that described that this tick inhabits both rural and urban environments but is particularly abundant in dogs from urban and peri-urban areas (Jones et al., 2017; Cicuttin et al., 2015). The R. sanguineus complex is, probably, the most widely distributed group of ticks in the world and should be considered as one of the most important ectoparasites of dogs throughout Latin America (Dantas-Torres, 2008; Venzal et al., 2007). The role of $R$. sanguineus in the transmission of tick-borne pathogens in humans is often not considered important due to the low affinity of $R$. sanguineus to feed on this host; however, there are some reports confirming frequent human exposure to this ticks in different countries (Harrison et al., 1997; Estrada-Peña \& Jongejan, 1999; Dantas-Torres et al., 2006; Guglielmone et al., 2006; Dantas-Torres, 2008). In addition, there is evidence that during periods of warmer temperatures $R$. sanguineus increases its aggressiveness and propensity to bite hosts other than dogs, including humans (Parola et al., 2008).

Different reports have shown that in the New World, the taxon $R$. sanguineus encompasses at least two different species, the formerly temperate lineage or $R$. sanguineus sensu stricto (s.s.), and a yet to be defined species, the so-called tropical lineage of $R$. sanguineus s.I. (Moraes-Filho et al., 2011,2015; Nava et al., 2018). Among these two 
species, only $R$. sanguineus s.l. tropical lineage has been reported in Colombia and other tropical regions of South America (Moraes-Filho et al., 2011; Rivera-Páez et al., 2018).

A previous study has experimentally demonstrated that $E$. canis was successfully transmitted by the $R$. sanguineus s.I. tropical lineage, but not by R. sanguineus S.s. (temperate lineage) (Moraes-Filho et al., 2015). Recent reports of cases of CME in dogs from $R$. sanguineus s.s.-prevailing areas of Argentina suggest that this temperate lineage may have some degree of vector capacity for $E$. canis or that $R$. sanguineus s.l. tropical lineage infected with $E$. canis is migrating to these areas, probably when climatic conditions are favorable to the temporary establishment and infection of susceptible hosts (Cicuttin et al., 2017; Tarragona et al., 2019).

$R$. sanguineus s.l. tropical lineage is distributed from southern Brazil to northern Mexico and the United States and is the only lineage that has been reported in Colombia (Moraes-Filho et al., 2011; Dantas-Torres et al., 2013). Although in our study, the taxon of $R$. sanguineus was not identified, we expect that it belongs to the tropical lineage considering the geographic location and that $E$. canis was the most prevalent tick-borne pathogen in both dogs (IFA: 82\% PCR: 18\%) and ticks (PCR: 30.4\%). In addition, our previous results showed the presence of three genotypes of E. canis (strain United States, Brazil, and Costa Rica) infecting dogs in Colombia, in which one of these strains has been associated with human infection in Costa Rica (Arroyave et al., 2020; Bouza-Mora et al., 2017).

Despite the small number of studies regarding $A$. platys published in Colombia, all of them are consistent in showing positive seroprevalence in canines, even with frequencies above 40\% (McCown et al., 2014a,b). We found anti-Anaplasma spp. antibodies in $8 \%(24 / 300)$ of plasma samples by ELISA; this frequency is comparable to a previous results in the same area that reported $11 \%$ of dogs having antibodies against $A$. platys (McCown et al., 2014a). Notably, 16 of 24 samples were also reactive to Ehrlichia spp., demonstrating the frequency of co-infection.

In the present work, the distribution of $E$. canis and $A$. platys overlapped where $R$. sanguineus s.l. was the only tick found on the dogs that came from the urban area, suggesting that both agents may share the same vector. The high percentage of nymphs and adults of this tick infected with $A$. platys reinforces the hypothesis that $R$. sanguineus s.l. ticks have vector competence to transmit A. platys (Ramos et al., 2014; Carvalho et al., 2017; Cicuttin et al., 2015; De Almeida et al., 2012; da Silva et al., 2016). However, the first experimental study attempting to confirm $R$. sanguineus s.l. as a vector of $A$. platys was unsuccessful (Simpson et al., 1991). The attempt to prove the vectorial competence of this tick species likely failed due to the low sensitivity of the diagnostic method or the tick lineage of R. sanguineus (Dantas-Torres et al., 2013; Ramos et al., 2014; Moraes-Filho et al., 2015). A more recent study reveals the trans-stadial transmission of $A$. platys in $R$. sanguineus s.l. from larvae to nymph and nymph to adults, although the lineage involved as a vector was not confirmed (Aktas \& Özübek, 2017). Our results reinforce the hypothesis that $R$. sanguineus s.l. tropical lineage is involved in the transmission of $A$. platys, since A. platys DNA was found in 6 of 69 pools (MIR: 3.4\%) of $R$. sanguineus s.l. removed from dogs that did not test positive for Anaplasma spp. by serologic or molecular means, indicating that these ticks likely acquired this agent in the previous life stage.

Natural and experimental evidence of co-infection of dogs with E. canis and A. platys has been reported (Sainz et al., 2015; Santamaria et al., 2014; Gaunt et al., 2010). In the current study, we show evidence of co-infection in 16 dogs with serological response against both agents, although, co-infection through detection of DNA of $E$. canis and $A$. platys was only found in two adult tick pools and in one dog. Co-infection with $E$. canis and A. platys contributes to atypical manifestations of disease including increased severity of clinical signs and exaggerated hematological abnormalities (Kordick et al., 1999). However, we did not find hematological differences among the dogs infected with E. canis or A. platys, and the dog infected with both agents.

Our results showed serological evidence of exposure to SFG rickettsiae in eight dogs. Of these, three showed endpoint titers to $R$. parkeri with at least 4-fold higher than those to any of the other four antigens suggesting that this rickettsia was involved in the infection. The remaining five samples with low titers to SFG rickettsiae were considered undetermined, suggesting that other Rickettsia species not present in our antigens stimulated the antibody response. Previous studies in dogs experimentally infected with $R$. rickettsii (pathogenic) and $R$. montanensis (non-pathogenic) have shown that the non-pathogenic species stimulate low antibody responses ( 1:64) compared with the pathogenic species (Breitschwerdt et al., 1988). In the present study, some of the indeterminate samples showed low titers (1:64 to 1:128) suggesting that dogs may have been infected with a non-pathogenic rickettsia.

R. parkeri strain Atlantic rainforest emerged in 2010 in Brazil causing febrile illnesses in humans (Spolidorio et al., 2010; Silva et al., 2011). One year later R. parkeri was isolated from Amblyomma ovale ticks collected on a free-roaming domestic dogs in a rural area from Colombia (Londoño et al., 2014). Experimental studies have shown that $A$. ovale is a reservoir and competent vector of $R$. parkeri strain Atlantic rainforest (Krawczak et al., 2016; Brustolin et al., 2018). Endemic regions of $R$. parkeri strain Atlantic rainforest are associated with rural areas, especially areas with 
vegetation (forest, pastures) where the adult stage of $A$. ovale attaches to and feeds on dogs, which typically become infested in the forest (Szabó et al., 2013). Medellin is primarily an urban area and the second most important city in Colombia, but border areas are essentially composed of forest where wildlife abounds, which could provide optimal conditions for the establishment of $A$. ovale. Common activities in these areas can make dogs have access to forest fragments and become infested and carry infected ticks to homes, becoming a risk to humans.

$R$. rickettsii, the etiologic agent of RMSF, is the most severe tick-borne disease in the New World. Dogs and both R. sanguineus S.S and the tropical lineage, have been involved in two recent outbreaks of RMSF in Arizona (USA) and Sonora and Baja California (Mexico), respectively (Demma et al., 2006; Álvarez-Hernández et al., 2017). However, in South America, the role of $R$. sanguineus in the transmission of RMSF remains a source of speculation (Labruna et al., 2008; Piranda et al., 2011). Our current results detected no evidence of rickettsial DNA in R. sanguineus s.l. ticks, and serologically we have not demonstrated $R$. rickettsii infection in our tested dogs. In contrast; in a previous study, we showed 4-fold higher antibody titters (by IFA) against $R$. rickettsii compared to other Rickettsia species on two dogs from a rural area close to Medellín, and related with a cluster of lethal SFG human cases (Londoño et al. 2019).

\section{Conclusions}

Ours serologic and molecular findings confirm to $E$. canis and $A$. platys as a main TBRP infecting dogs in this study and $R$. sanguineus s.l. is likely involved in the transmission of both agents. More studies are needed to elucidate the role of $R$. sanguineus as a vector of $A$. platys in America. We also show serological evidence of exposure of dogs to SFG rickettsiae, which supports the likely role of dogs as sentinels for human infection by TBRP.

\section{Acknowledgments}

We are grateful to the veterinarians from the companion animal hospitals at the University of Antioquia, and to University CES, especially to Dr. Maria Soledad Gonzalez who participated in the sample and data collections. This work was supported by Colciencias, grant $585-2013$.

\section{Reference}

Acevedo-Gutiérrez L, Arboleda M, Ospina D, Avila AM, Díaz FJ, Rodas JD. Unprecedented human infection with Rickettsia parkeri strain Atlantic rainforest in Northwestern Colombia: case report. Am J Trop Med Hyg 2019; 99(Suppl 4): $163-164$.

Agudelo-Ruíz Y, Acevedo-Gutiérrez L, Montoya-Sanchéz A, Paternina TL, Rodas J. Identificación molecular de hemoparásitos transmitidos por garrapatas en equinos del Noroeste de Colombia. Rev Mvz Cordoba 2017; 22(Suppl): $6004-6017$.

Aktas M, Özübek S. Molecular evidence for trans-stadial transmission of Anaplasma platys by Rhipicephalus sanguineus sensu lato under field conditions. Med Vet Entomo/ 2017; 32(1): 78-83. http://dx.doi.org/10.1111/mve.12261. PMid:28815682.

Almeida ADBPF, Paula DAJ, Dahroug MAA, Freitas AG, Silva JN, Dutra V, et al. Ehrlichia canis e Anaplasma platys em carrapatos de cães de Cuiabá Mato Grosso. Semina: Ciênc Agrár 2012; 33(3): 1123-1126. http://dx.doi.org/10.5433/1679-0359.2012v33n3p1123.

Álvarez-Hernández G, Roldán JFG, Milan NSH, Lash RR, Behravesh CB, Paddock CD. Rocky Mountain spotted fever in Mexico: past, present, and future. Lancet Infect Dis 2017; 17(6): e189-e196. http://dx.doi.org/10.1016/S1473-3099(17)30173-1. PMid:28365226.

Anderson BE, Maupin GO, Piesman JF, Johnson BJB, Sims KG, Happ CM, et al. Amblyomma americanum: a potential vector of human ehrlichiosis. Am J Trop Med Hyg 1993; 49(2): 239-244. http://dx.doi.org/10.4269/ajtmh.1993.49.239. PMid:8357086.

Arroyave E, Rodas-González JD, Zhang X, Labruna MB, González MS, Fernández-Silva JA, et al. Ehrlichia canis TRP36 diversity in naturally infected-dogs from an urban area of Colombia. Ticks Tick Borne Dis 2020; 11(3): 101367. http://dx.doi.org/10.1016/j. ttbdis.2019.101367. PMid:31987818.

Bossa-Miranda MA, Valencia-Celis V, Carvajal-Giraldo B, Ríos-Osorio L. Valores de referencia del hemograma en perros sanos entre 1 y 6 años de edad, atendidos en el Hospital Veterinario - Universidad de Antioquia, 2002-2009. Rev Colomb Cienc Pecu 2012; 25(3): 409-416.

Bouza-Mora L, Dolz G, Solórzano-Morales A, Romero-Zuñiga JJ, Salazar-Sánchez L, Labruna MB, et al. Novel genotype of Ehrlichia canis detected in samples of human blood bank donors in Costa Rica. Ticks Tick Borne Dis 2017; 8(1): 36-40. http://dx.doi. org/10.1016/j.ttbdis.2016.09.012. PMid:27682202.

Breitschwerdt EB, Meuten DJ, Walker DH, Levy MG, Kennedy K, King M, et al. Canine Rocky Mountain spotted fever: a kennel epizootic. Am J Vet Res 1985; 46(10): 2124-2128. PMid:4062017. 
Breitschwerdt EB, Walker DH, Levy MG, Burgdorfer W, Corbett WT, Hurlbert S, et al. Clinical hematologic and humoral immune response in female dogs inoculated with Rickettsia rickettsii and Rickettsia montana. Am J Vet Res 1988; 49(1): 70-76. PMid:3128147.

Brustolin JM, Silva Krawczak F, Alves MEM, Weiller MA, Souza CL, Rosa FB, et al. Experimental infection in Cavia porcellus by infected Amblyomma ovale nymphs with Rickettsia sp. (Atlantic rainforest strain). Parasitol Res 2018; 117(3): 713-720. http://dx.doi. org/10.1007/s00436-017-5741-2. PMid:29374783.

Cárdenas AM, Doyle CK, Zhang X, Nethery K, Corstvet RE, Walker DH, et al. Enzyme-linked immunosorbent assay with conserved immunoreactive glycoproteins gp36 and gp19 has enhanced sensitivity and provides species-specific immunodiagnosis of Ehrlichia canis infection. Clin Vaccine Immunol 2007; 14(2): 123-128. http://dx.doi.org/10.1128/CVI.00361-06. PMid:17151186.

Carvalho L, Armua-Fernandez MT, Sosa N, Félix ML, Venzal JM. Anaplasma platys in dogs from Uruguay. Ticks Tick Borne Dis 2017; 8(2): 241-245. http://dx.doi.org/10.1016/j.ttbdis.2016.11.005. PMid:27908772.

Cicuttin GL, De Salvo MN, Silva DA, Brito M, Nava S. Ehrlichia canis (Rickettsiales: Anaplasmataceae) en garrapatas Rhipicephalus sanguineus sensu lato del linaje templado (Acari: Ixodidae), provincia de Buenos Aires, Argentina. FAVE, Secc Cienc vet (En línea) 2017: 16(2): 93-96.

Cicuttin GL, Rodríguez Vargas M, Jado I, Anda P. Primera detección de Rickettsia massiliae en la ciudad de Buenos Aires. Rev Argentina Zoonosis 2004; 1(1): 8-10.

Cicuttin GL, Tarragona EL, De Salvo MN, Mangold AJ, Nava S. Infection with Ehrlichia canis and Anaplasma platys (Rickettsiales: Anaplasmataceae) in two lineages of Rhipicephalus sanguineus sensu lato (Acari: Ixodidae) from Argentina. Ticks Tick Borne Dis 2015; 6(6): 724-729. http://dx.doi.org/10.1016/j.ttbdis.2015.06.006. PMid:26100492.

Dantas-Torres F, Figueredo LA, Brandão-Filho SP. Rhipicephalus sanguineus (Acari: Ixodidae), the brown dog tick, parasitizing humans in Brazil. Rev Soc Bras Med Trop 2006; 39(1): 64-67. http://dx.doi.org/10.1590/S0037-86822006000100012. PMid:16501769.

Dantas-Torres F, Latrofa MS, Annoscia G, Giannelli A, Parisi A, Otranto D. Morphological and genetic diversity of Rhipicephalus sanguineus sensu lato from the New and Old Worlds. Parasit Vectors 2013; 6(1): 213. http://dx.doi.org/10.1186/1756-3305-6-213. PMid:23880226.

Dantas-Torres F. The brown dog tick, Rhipicephalus sanguineus (Latreille, 1806) (Acari: Ixodidae): from taxonomy to control. Vet Parasito/ 2008; 152(3-4): 173-185. http://dx.doi.org/10.1016/j.vetpar.2007.12.030. PMid:18280045.

Demma LJ, Traeger M, Blau D, Gordon R, Johnson B, Dickson J, et al. Serologic evidence for exposure to Rickettsia rickettsii in eastern Arizona and recent emergence of Rocky Mountain spotted fever in this Region. Vector Borne Zoonotic Dis 2006; 6(4): 423-429. http://dx.doi.org/10.1089/vbz.2006.6.423. PMid:17187578.

Demma LJ, Traeger MS, Nicholson WL, Paddock CD, Blau DM, Eremeeva ME, et al. Rocky Mountain spotted fever from an unexpected tick vector in Arizona. N Eng/J Med 2005; 353(6): 587-594. http://dx.doi.org/10.1056/NEJMoa050043. PMid:16093467.

Doyle CK, Labruna MB, Breitschwerdt EB, Tang YW, Corstvet RE, Hegarty BC, et al. Detection of medically important Ehrlichia by quantitative multicolor TaqMan real-time polymerase chain reaction of the $d s$ gene.J Mol Diagn 2005; 7(4): 504-510. http:// dx.doi.org/10.1016/S1525-1578(10)60581-8. PMid:16237220.

Estrada-Peña A, Jongejan F. Ticks feeding on humans: a review of records on human-biting Ixodoidea with special reference to pathogen transmission. Exp Appl Acarol 1999; 23(9): 685-715. http://dx.doi.org/10.1023/A:1006241108739. PMid:10581710.

Fang R, Blanton LS, Walker DH. Rickettsiae as emerging infectious agents. Clin Lab Med 2017; 37(2): 383-400. http://dx.doi. org/10.1016/j.cll.2017.01.009. PMid:28457356.

Gaunt SD, Beall MJ, Stillman BA, Lorentzen L, Diniz VP, Chandrashekar R, et al. Experimental infection and co-infection of dogs with Anaplasma platys and Ehrlichia canis: Hematologic, serologic and molecular findings. Parasit Vectors 2010; 3(1): 33. http:// dx.doi.org/10.1186/1756-3305-3-33. PMid:20377870.

GeneStudio. [online]. 2020 [cited 2020 Jan 17]. Available from: http://genestudio.com/

Grindem CB, Breitschwerdt EB, Perkins PC, Cullins LD, Thomas TJ, Hegarty BC. Platelet-associated immunoglobulin (antiplatelet antibody) in canine Rocky Mountain spotted fever and ehrlichiosis. J Am Anim Hosp Assoc 1999; 35(1): 56-61. http://dx.doi. org/10.5326/15473317-35-1-56. PMid:9934930.

Guglielmone AA, Beati L, Barros-Battesti DM, Labruna MB, Nava S, Venzal JM, et al. Ticks (Ixodidae) on humans in South America. Exp Appl Acarol 2006; 40(2): 83-100. http://dx.doi.org/10.1007/s10493-006-9027-0. PMid:17103085.

Harrison BA, Engber BR, Apperson CS. Ticks (Acari: Ixodida) uncommonly found biting humans in North Carolina. J Vector Ecol 1997; 22(1): 6-12. PMid:9221733.

Harvey JW. Thrombocytotrophic anaplasmosis (A. platys [E. platys] infection). In: Green CE, editor. Infectious diseases of the dog and cat. 3rd ed. St. Louis: Saunders Elsevier; 2006. p. 229-232. 
Hidalgo M, Lizarazo D, Valbuena G, Vesga JF. A survey of antibodies against Rickettsia rickettsii and Ehrlichia chafeensis in domestic animals from a rural area of Colombia. Am J Trop Med Hyg 2009; 80(6): 1029-1030. http://dx.doi.org/10.4269/ajtmh.2009.80.1029. PMid:19478270.

Hidalgo M, Orejuela L, Fuya P, Carrillo P, Hernandez J, Parra E, et al. Rocky Mountain spotted fever, Colombia. Emerg Infect Dis 2007; 13(7): 1058-1060. http://dx.doi.org/10.3201/eid1307.060537. PMid:18214179.

Horta MC, Labruna MB, Sangioni LA, Vianna MCB, Gennari SM, Galvão MAM, et al. Prevalence of antibodies to spotted fever group rickettsiae in humans and domestic animals in a Brazilian spotted fever-endemic area in the state of São Paulo Brazil: serologic evidence for infection by Rickettsia rickettsii and another spotted fever group Rickettsia. Am J Trop Med Hyg 2004; 71(1): 93-97. http://dx.doi.org/10.4269/ajtmh.2004.71.93. PMid:15238696.

Inokuma H, Fujii K, Okuda M, Onishi T, Beaufils J, Raoult D, et al. Determination of the Nucleotide Sequences of Heat Shock Operon groESL and the Citrate Synthase Gene ( $g / t A)$ of Anaplasma (Ehrlichia) platys for phylogenetic and diagnostic studies. Clin Diagn Lab Immunol 2002; 9(5): 1132-1136. PMid:12204973.

Inokuma H, Raoult D, Brouqui P. Detection of Ehrlichia platys DNA in brown dog ticks (Rhipicephalus sanguineus) in Okinawa Island, Japan. J Clin Microbio/ 2000; 38(11): 4219-4221. http://dx.doi.org/10.1128/JCM.38.11.4219-4221.2000. PMid:11060094.

Ipek NDS, Özübek S, Aktas M. Molecular evidence for transstadial transmission of Ehrlichia canis by Rhipicephalus sanguineus sensu lato under field conditions. J Med Entomol 2018; 55(2): 440-444. http://dx.doi.org/10.1093/jme/tjx217. PMid:29272463.

Jones EO, Gruntmeir JM, Hamer SA, Little SE. Temperate and tropical lineages of brown dog ticks in North America. Vet Parasitol Reg Stud Rep 2017; 7: 58-61. http://dx.doi.org/10.1016/j.vprsr.2017.01.002. PMid:31014659.

Kordick SK, Breitschwerdt EB, Hegarty BC, Southwick KL, Colitz CM, Hancock SI, et al. Coinfection with multiple tick-borne pathogens in a Walker Hound kennel in North Carolina. J Clin Microbiol 1999; 37(8): 2631-2638. http://dx.doi.org/10.1128/JCM.37.8.26312638.1999. PMid:10405413.

Krawczak FS, Agostinho WC, Polo G, Moraes-FilhoJ, Labruna MB. Comparative evaluation of Amblyomma ovale ticks infected and noninfected by Rickettsia sp. strain Atlantic rainforest, the agent of an emerging rickettsiosis in Brazil. Ticks Tick Borne Dis 2016; 7(3): 502-507. http://dx.doi.org/10.1016/j.ttbdis.2016.02.007. PMid:26895674.

Labruna MB, Kamakura O, Moraes-Filho J, Horta MC, Pacheco RC. Rocky Mountain spotted fever in dogs, Brazil. Emerg Infect Dis 2009; 15(3): 458-460. http://dx.doi.org/10.3201/eid1503.081227. PMid:19239764.

Labruna MB, Ogrzewalska M, Martins TF, Pinter A, Horta MC. Comparative Susceptibility of Larval Stages of Amblyomma aureolatum, Amblyomma cajennense, and Rhipicephalus sanguineus to Infection by Rickettsia rickettsii. J Med Entomol 2008; 45(6): $1156-1159$. http://dx.doi.org/10.1603/0022-2585(2008)45[1156:CSOLSO]2.0.CO;2. PMid:19058642.

Levin ML, Killmaster LF, Zemtsova GE, Ritter JM, Langham G. Clinical presentation, convalescence, and relapse of rocky mountain spotted fever in dogs experimentally infected via tick bite. PLoS One 2014; 9(12): e115105. http://dx.doi.org/10.1371/journal. pone.0115105. PMid:25542001.

Londoño AF, Arango-Ferreira C, Acevedo-Gutiérrez LY, Paternina LE, Montes C, Ruiz l, et al. A cluster of cases of rocky mountain spotted fever in an area of colombia not known to be endemic for this disease. Am J Trop Med Hyg 2019; 101(2): 336-342. http:// dx.doi.org/10.4269/ajtmh.18-1007. PMid:31162015.

Londoño AF, Díaz FJ, Valbuena G, Gazi M, Labruna MB, Hidalgo M, et al. Infection of Amblyomma ovale by Rickettsia sp. strain Atlantic rainforest Colombia. Ticks Tick Borne Dis 2014; 5(6): 672-675. http://dx.doi.org/10.1016/j.ttbdis.2014.04.018. PMid:25090976.

McBride JW, Corstvet RE, Breitschwerdt EB, Walker DH. Immunodiagnosis of Ehrlichia canis infection with recombinant proteins. J Clin Microbiol 2001; 39(1): 315-322. http://dx.doi.org/10.1128/JCM.39.1.315-322.2001. PMid:11136790.

McCown ME, Alleman A, Sayler KA, Chandrashekar R, Thatcher B, Tyrrell P, et al. Point prevalence survey for tick-borne pathogens in military working dogs, shelter animals, and pet populations in northern Colombia. J Spec Oper Med 2014a; 14(4): 81-85. PMid:25399372.

McCown ME, Monterroso VH, Cardona W. Surveillance for Ehrlichia canis, Anaplasma phagocytophilum, Borrelia burgdorferi, and Dirofilaria immitis in dogs from three cities in Colombia.J Spec Oper Med 2014b; 14(1): 86-90. PMid:24604443.

Moraes-Filho J, Krawczak FS, Costa FB, Soares JF, Labruna MB. Comparative evaluation of the vector competence of four South American populations of the Rhipicephalus sanguineus group for the bacterium Ehrlichia canis, the agent of canine monocytic ehrlichiosis. PLoS One 2015; 10(9): e0139386. http://dx.doi.org/10.1371/journal.pone.0139386. PMid:26414283.

Moraes-Filho J, Marcili A, Nieri-Bastos FA, Richtzenhain LJ, Labruna MB. Genetic analysis of ticks belonging to the Rhipicephalus sanguineus group in Latin America. Acta Trop 2011; 117(1): 51-55. http://dx.doi.org/10.1016/j.actatropica.2010.09.006. PMid:20858451.

Murrell A, Campbell N, Barker S. Mitochondrial 12S rDNA indicates that the Rhipicephalinae (Acari: Ixodida: Ixodidae) is paraphyletic. Mol Phylogenet Evol 1999; 12(1): 83-86. http://dx.doi.org/10.1006/mpev.1998.0595. PMid:10222164. 
Nava S, Beati L, Venzal JM, Labruna MB, Szabó MPJ, Petney TN, et al. Rhipicephalus sanguineus (Latreille, 1806): neotype designation, morphological re-description of all parasitic stages and molecular characterization. Ticks Tick Borne Dis 2018; 9(6): $1573-1585$. http://dx.doi.org/10.1016/j.ttbdis.2018.08.001. PMid:30100385.

Nieri-Bastos FA, Szabó MPJ, Pacheco RC, Soares JF, Soares HS, Moraes-Filho J, et al. Comparative evaluation of infected and noninfected Amblyomma triste ticks with Rickettsia parkeri the agent of an emerging rickettsiosis in the new world. BioMed Res Int 2013; 2013: 402737. http://dx.doi.org/10.1155/2013/402737. PMid:23936795.

Onofrio VC, Venzal JM, Pinter A, Szabó MPJ. Família Ixodidae: características gerais, comentários e chave para gêneros. In: BarrosBattesti DM, Arzua M, Bechara GH, editors. Carrapatos de Importância Médico-Veterinária da Região Neotropical: Um guia ilustrado para identificação de espécies. São Paulo: Vox/ICTTD-3/Butantan; 2006. p. 29-39.

Oteo JA, Nava S, Sousa R, Mattar S, Venzal JM, Labruna MB, et al. Guías Latinoamericanas de la RIICER para el diagnóstico de las rickettsiosis transmitidas por garrapatas. Rev Chil Infectol 2014; 31(1): 54-65.

Parola P, Socolovschi C, Jeanjean L, Bitam I, Fournier PE, Sotto A, et al. Warmer weather linked to tick attack and emergence of severe rickettsioses. PLoS Neg/ Trop Dis 2008; 2(11): e338. http://dx.doi.org/10.1371/journal.pntd.0000338. PMid:19015724.

Patiño L, Afanador A, Paul JH. A spotted fever in Tobia, Colombia. Am J Trop Med 1937; s1-17(5): 639-653. https://doi.org/10.4269/ ajtmh.1937.s1-17.639.

Patiño L. Nuevas observaciones sobre un tercer foco de fiebre petequial (maculosa) en el hemisferio Americano. Bol Sanit Panam 1941; 20(11): 1112-1124.

Piranda EM, Faccini JLH, Pinter A, Pacheco RC, Cancado PHD, Labruna MB. Experimental infection of Rhipicephalus sanguineus ticks with the bacterium Rickettsia rickettsii, using experimentally infected dogs. Vector Borne Zoonot Dis 2011; 11(1): 29-36.

Piranda EM, Faccini JLH, Pinter A, Saito TB, Pacheco RC, Hagiwara MK, et al. Experimental infection of dogs with a Brazilian strain of Rickettsia rickettsii: clinical and laboratory findings. Mem Inst Oswaldo Cruz 2008; 103(7): 696-701. http://dx.doi.org/10.1590/ S0074-02762008000700012. PMid:19057821.

Ramos RAN, Latrofa MS, Giannelli A, Lacasella V, Campbell BE, Dantas-Torres F, et al. Detection of Anaplasma platys in dogs and Rhipicephalus sanguineus group ticks by a quantitative real-time PCR. Vet Parasitol 2014; 205(1-2): 285-288. http://dx.doi. org/10.1016/j.vetpar.2014.06.023. PMid:25027609.

Rar V, Golovljova I. Anaplasma, Ehrlichia and "Candidatus Neoehrlichia" bacteria: pathogenicity, biodiversity and molecular genetic characteristics, a review. Infect Genet Evo/ 2011; 11(8): 1842-1861. http://dx.doi.org/10.1016/j.meegid.2011.09.019. PMid:21983560.

Rivera-Páez FA, Labruna MB, Martins TF, Perez JE, Castaño-Villa GJ, Ossa-López PA, et al. Contributions to the knowledge of hard ticks (Acari: Ixodidae) in Colombia. Ticks Tick Borne Dis 2018; 9(1): 57-66. http://dx.doi.org/10.1016/j.ttbdis.2017.10.008 PMid:29055642.

Sabatini GS, Pinter A, Nieri-Bastos F, Marcili A, Labruna MB. Survey of ticks (Acari: Ixodidae) and their Rickettsia in an Atlantic rainforest reserve in the State of São Paulo Brazil. J Med Entomol 2010; 47(5): 913-916. http://dx.doi.org/10.1093/jmedent/47.5.913. PMid:20939390.

Sainz A, Roura X, Miró G, Estrada-Peña A, Kohn B, Harrus S, et al. Guideline for veterinary practitioners on canine ehrlichiosis and anaplasmosis in Europe. Parasit Vectors 2015; 8(1): 75. http://dx.doi.org/10.1186/s13071-015-0649-0. PMid:25649069.

Saito TB, Cunha-Filho NA, Pacheco RC, Ferreira F, Pappen FG, Farias NAR, et al. Canine infection by rickettsiae and ehrlichiae in southern Brazil. Am J Trop Med Hyg 2008; 79(1): 102-108. http://dx.doi.org/10.4269/ajtmh.2008.79.102. PMid:18606772.

Santamaria A, Calzada JE, Saldaña A, Yabsley MJ, Gottdenker NL. Molecular diagnosis and species identification of Ehrlichia and Anaplasma Infections in dogs from Panama, Central America. Vector Borne Zoonotic Dis 2014; 14(5): 368-370. http://dx.doi. org/10.1089/vbz.2013.1488. PMid:24746012.

Silva CBD, Santos HA, Navarrete MG, Ribeiro CCDU, Gonzalez BC, Zaldivar MF, et al. Molecular detection and characterization of Anaplasma platys in dogs and ticks in Cuba. Ticks Tick Borne Dis 2016; 7(5): 938-944. http://dx.doi.org/10.1016/j.ttbdis.2016.04.012. PMid:27132516.

Silva N, Eremeeva ME, Rozental T, Ribeiro GS, Paddock CD, Ramos EA, et al. Eschar-associated spotted fever rickettsiosis, Bahia, Brazil. Emerg Infect Dis 2011; 17(2): 275-278. http://dx.doi.org/10.3201/eid1702.100859. PMid:21291605.

Simpson RM, Gaunt SD, Hair JA, Kocan KM, Henk WG, Casey HW. Evaluation of Rhipicephalus sanguineus as a potential biologic vector of Ehrlichia platys. Am J Vet Res 1991; 52(9): 1537-1541. PMid:1952347.

Spolidorio MG, Labruna MB, Mantovani E, Brandão PE, Richtzenhain LJ, Yoshinari NH. Novel spotted fever group rickettsiosis Brazil. Emerg Infect Dis 2010; 16(3): 521-523. http://dx.doi.org/10.3201/eid1603.091338. PMid:20202436.

Stillman B, Monn M, Liu J, Thatcher B, Foster P, Andrews B, et al. Performance of a commercially available in-clinic ELISA for detection of antibodies against Anaplasma phagocytophilum, Anaplasma platys, Borrelia burgdorferi, Ehrlichia canis, and Ehrlichia 
ewingii and Dirofilaria immitis antigen in dogs. J Am Vet Med Assoc 2014; 245(1): 80-86. http://dx.doi.org/10.2460/javma.245.1.80. PMid:24941391.

Szabó M, Nieri-Bastos FA, Spolidorio M, Martins T, Barbieri AM, Labruna M. In vitro isolation from Amblyomma ovale (Acari: Ixodidae) and ecological aspects of the Atlantic rainforest Rickettsia, the causative agent of a novel spotted fever rickettsiosis in Brazil. Parasitology 2013; 140(6): 719-728. http://dx.doi.org/10.1017/S0031182012002065. PMid:23363571.

Tarragona EL, Flores FS, Herrera CL, Dalinger M, Aguirre N, Monje LD, et al. Primer reporte de un caso de ehrlichiosis monocítica canina en la provincia de Santa Fe, Argentina. FAVE, Secc Cienc vet (En línea) 2019; 18(2): 49-54.

Venzal JM, Estrada Pena A, Castro O, De Souza CG, Portillo A, Oteo JA. Study on seasonal activity in dogs and ehrlichial infection in Rhipicephalus sanguineus (Latreille, 1806) (Acari: Ixodidae) from southern Uruguay. Parasitol Latinoam 2007; 62(1-2): 23-26. http://dx.doi.org/10.4067/S0717-77122007000100004. 